\title{
Erratum to: "Release and Retention Patterns of Organic Compounds and Nutrients after the Cold Period in Foliar Litterfall of Pure European Larch, Common Beech and Red Oak Plantations in Lithuania" [Eurasian Soil Science 50, 49 (2017)] ${ }^{1}$
}

D. Čiuldiené $\dot{\mathrm{e}}^{a, *}$, J. Aleinikoviené ${ }^{b}$, M. Muraškiené ${ }^{a}$, V. Marozas ${ }^{b}$, and K. Armolaitis ${ }^{a, c}$

${ }^{a}$ Institute of Forestry, Lithuanian Research Centre for Agriculture and Forestry,

Liepu 1, LT-53101 Girionys, Kaunas district, Lithuania

${ }^{b}$ Faculty of Forestry and Ecology, Aleksandras Stulginskis University,

Studentu 11, LT-53361 Akademija, Kaunas district, Lithuania

${ }^{c}$ Faculty of Natural Science, Vytautas Magnus University, Vileikos 8, LT-44404 Kaunas, Lithuania

*e-mail: d.ciuldiene@gmail.com

Submitted March 13, 2017; accepted for publication March 14, 2017

DOI: $10.1134 / \mathrm{S} 1064229317060138$

Figure 1 should be:

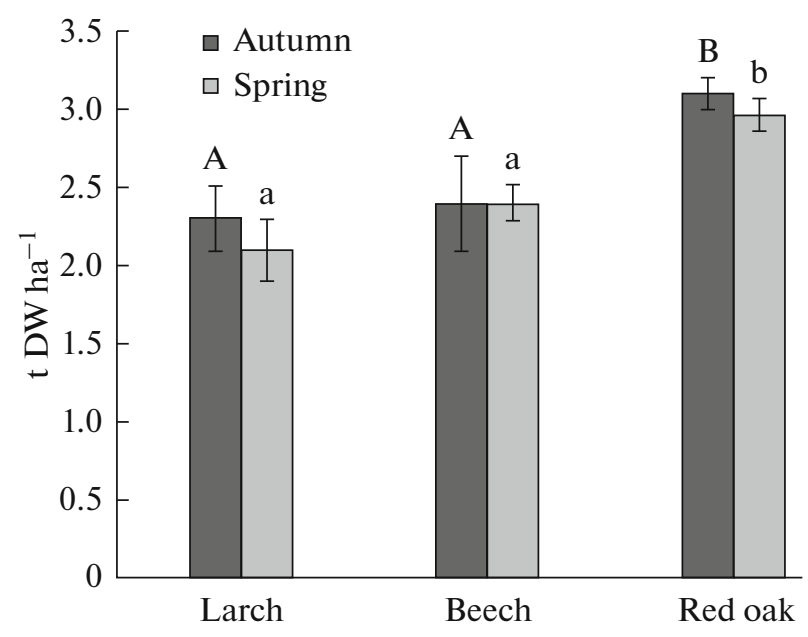

Figure 1. The dry mass of foliar litterfall collected in autumn and in spring. The data represent mean \pm SE. Different letters indicate significant differences $(p<0.05)$ between the mean dry mass of foliar litterfall determined in autumn (capital letters) and in spring (lower case letters).

\footnotetext{
${ }^{1}$ The article was translated by the authors.
} 